\title{
Serological and Molecular Study of Newcastle Disease Virus in Village Chickens in Selected Rift-Valley Areas, Ethiopia
}

\author{
Dehinenet Terefe $^{1}$, Redeat Belaineh ${ }^{2}$, Hassen Chaka ${ }^{2}$, Melaku Sombo ${ }^{2}$, Abebe Mekuria ${ }^{1}$, Getachew Gugsa ${ }^{1}$, Kumela Lelisa ${ }^{3}$ and Delesa Damena ${ }^{2}$ \\ ${ }^{1}$ Mekele University College of Veterinary Medicine, Mekele, Tigrai, Ethiopia \\ ${ }^{2}$ National Animal Health Diagnostic and Investigation Center, Sebeta, Oromia, Ethiopia \\ ${ }^{3}$ National Institute for Control and Eradication of Tsetse and Trypanosomosis; Addis Ababa, Ethiopia
}

*Corresponding author: Delesa Damena, National Animal Health Diagnostic and Investigation Center, Sebeta, Oromia, Ethiopia, Tel: +251-911771998; E-mail: delesa_damenaa@yahoo.com

Rec date: Jun 27, 2015; Acc date: Oct 03, 2015; Pub date: Oct 05, 2015

Copyright: $\odot 2015$ Terefe D, et al. This is an open-access article distributed under the terms of the Creative Commons Attribution License, which permits unrestricted use, distribution, and reproduction in any medium, provided the original author and source are credited.

\begin{abstract}
Newcastle Disease (ND) is a serious and commonly fatal viral poultry disease, which is widely distributed throughout the world. In most developing countries including Ethiopia, ND is the most important disease causing huge economic losses. A cross sectional study was conducted in February 2014 in village chickens at three selected districts in and around rift valley lakes of Ethiopia to determine the prevalence of Newcastle disease virus (NDV) by serological and molecular methods. A total of 155 sera and 155 swab samples were collected from village chickens in Bishoftu, Tikur wuha and Ziway districts. The sera samples were analyzed by Competitive-ELISA. ND viruses were isolated from the tracheal swab specimens, through inoculation in embryonated chicken eggs and were characterized genetically by using molecular methods. Real-time RT-PCR targeting a conserved region of the M gene was employed to amplify all APMV1. M-gene positive samples were further analyzed by Real-time RT-PCR targeting F-gene to specifically amplify the virulent strains. The overall sero prevalence of ND was $11.6 \%$ with no statistically significant differences between the study districts at $95 \%$ confidence level. Thirteen isolates were positive for APMV1 out of which $38.4 \%(5 / 13)$ were virulent NDV strains. This study provides important information on serological and virological profile of NDV and highlights the importance of continuous surveillances to better understand the epidemiology of the disease.
\end{abstract}

Keywords: Newcastle disease; Village chickens; Real-time RT-PCR; Competitive-ELISA; Ethiopia

\section{Introduction}

Free-range rural chicken population dominates the poultry industry in developing countries. It provides off-farm employment and income generating opportunity and serves as a source of gifts and religious sacrifices [1,2]. In Ethiopia, village poultry production has a long traditional practice which is mainly used as an immediate cash income for the rural communities, where women are more involved in keeping village chickens [3].

Despite its role in raising incomes and reducing poverty in local communities of Ethiopia, poultry production is hampered by wide arrays of constraints among which infectious diseases, such as: ND, infectious bursal disease, mycoplasmosis, pasteurellosis and salmonellosis, are the major ones [4]. ND is a highly contagious and devastating disease of poultry caused by the Newcastle disease virus (NDV) of avian paramyxovirus type-1(APMV-1). It is classified under the genus Avula virus of family paramyxovaridae [5]. NDV is an enveloped non-segmented, single-stranded negative-sense RNA virus with a helical morphology. Its genome has six open reading frames (ORF), which encode for the following proteins: nucleoprotein (NP), phosphoprotein $(\mathrm{P})$, matrix protein $(\mathrm{M})$, fusion protein $(\mathrm{F})$, hemagglutinin-neuraminidase $(\mathrm{HN})$ and RNA-dependent RNA polymerase (L). During P-gene transcription, two additional non structural proteins, the $\mathrm{V}$ and $\mathrm{W}$ proteins are also generated through RNA editing [6].
In Africa, serological and virological evidences have shown the presence of the disease in backyard poultry in many countries [7-9]. Previous sero-epidemiological investigations in different parts of Ethiopia, Zeleke et al. [10], Tadesse et al. [11], Chaka et al. [4] revealed the endemicity of ND in village chickens. Despite the fact that ND represents the most severe poultry disease responsible for marked economic losses across the country, there is scarcity of information on serological and virological status of the disease in village chickens in the study area. Hence, this study was conducted to determine the seroprevalence of ND and investigate NDV strains circulating in village chickens in selected districts in rift valley areas of Ethiopia.

\section{Materials and Methods}

\section{Sampling technique}

A total of 155 unvaccinated village chickens were randomly sampled in February 2014 from selected districts in rift valley areas including Bishoftu $(n=50)$, Tikur wuha $(n=55)$ and Ziway $(n=50)$. Two milliliter of chicken blood was collected through the brachial vein using a 21gauge sterile hypodermic needle and $2 \mathrm{ml}$ syringes. The syringes were labeled and kept in slanting position till clot formation. Sera were harvested, transferred into a sterile serum bottles. From each bird, tracheal swabs were collected and placed in sterile plastic screw capped vials containing virus transport media (VTM). The samples were then placed in iced plastic bags and transported to the National Animal Health Diagnosis and Investigation Center (NAHDIC), Sebeta, Ethiopia. 


\section{Enzyme Linked Immuno sorbent Assay (ELISA)}

NDV specific antibodies in the sera samples were analyzed using a competitive-ELISA following the manufacturer's recommended protocol. NDV-coated ELISA plates were first incubated with serum samples diluted by dilution buffer 2 for 30 minutes at room temperature. The NDV-specific horseradish peroxidase-labeled $\mathrm{mAb}$ was added to the wells, and incubated for further 30 minutes. The binding of the conjugated $\mathrm{mAb}$ was visualized with a substrate solution containing tetramethylbenzidine hydrochloride and hydrogen peroxide. The wells were washed three times between the incubation steps with the washing solution. The sample and control optical density (OD) values were read using an ELISA reader at $450 \mathrm{~nm}$. From the OD values, the percentage of inhibition (PI) was calculated for the control and the test samples.

\section{Virus Isolation}

Virus isolation was done from the swab samples by standard method using embryonated chicken eggs. Three embryonated chicken eggs of 9 to 11-day-old per sample were used for inoculation [12]. The eggs were disinfected and candled to check the viability and to delimit the air sac at less number of blood vessels. The eggs were drilled manually to make a small hole about $2 \mathrm{~mm}$ above the delimitation of the air sac and inoculated in allantoic cavity with 0.1-0.2 ml clarified supernatant obtained from the swabs after centrifugation at $1000 \mathrm{rpm}$ for 10 minutes. Finally, the eggs were sealed with glue and incubated at 37 o $\mathrm{C}$ for 4 days in an incubator. The inoculated eggs were candled every $24 \mathrm{hr}$ to check embryo vitality. Eggs containing dead embryo on each day and those remaining at the end of the incubation period, were removed from incubator and chilled at $+4^{\circ} \mathrm{C}$ overnight. The next day, allantoic fluids were harvested and tested by HA test for its ability to haemagglutinate chicken RBCs [12].

\section{Haemagglutination (HA)}

Haemagglutination test was performed in micro plate as outlined by the World organization for Animal Health [13]. Inactivated antigen for $\mathrm{HA}$ test and positive and negative sera for $\mathrm{HI}$ controls were obtained from Istituto Zooprofilattico Spermentale delle Venezie (OIE/FAO Reference Laboratory for AI and ND), Padua, Italy. The test was carried out by running twofold dilutions of equal volumes $(0.025 \mathrm{~mL})$ of phosphate buffered saline (PBS) and virus suspension $(0.025 \mathrm{~mL})$ in V-bottomed microtiter plates. Finally, $0.025 \mathrm{ml}$ of $1 \%$ (volume/volume) chicken red blood cells (RBCs) were added to each well and, after gentle mixing, allowed to settle for about 30 minutes at room temperature. The samples were read by holding the plate perpendicular to the bench, by holding it vertically, against a white background and observing the presence or absence of tear shaped streaming of the RBCs.

\section{Haemagglutination (HI)}

HA positive samples were tested by Heamaglutination Inhibition (HI) reaction to specifically determine the haemagglutinating agents. The HI test was done following procedures outlined by the Office International des Epizooties [13]. The test was carried out by running two fold dilutions of equal volumes $(0.025 \mathrm{ml})$ of phosphate buffered saline (PBS) and reference sera $(0.025 \mathrm{ml})$ in V-bottomed microtiter plates following the plate layout protocol. Four haemagglutinating units (4HAU) of virus/antigen were added to each well and the plates were left at room temperature for a minimum of 30 minutes. Finally,
$0.025 \mathrm{ml}$ of $1 \%$ (volume/volume) chicken red blood cells (RBCs) were added to each well and, after gentle mixing, allowed to settle for about 30 minutes at room temperature. The HI titer was read from the highest dilution of serum causing complete inhibition of 4 HAU of antigen. Haemagglutination inhibition was assessed by tilting the plates. Only those wells in which the RBCs stream at the same rate as the control wells (containing $0.025 \mathrm{~mL}$ RBCs and $0.05 \mathrm{ml} \mathrm{PBS}$ ) were considered to show inhibition.

\section{Polymerase chain reaction (PCR)}

RNA extraction from HI positive allantoic fluid was conducted using Qiagen ${ }^{\oplus}$ RNeasy Mini kit according to manufacturer's instruction. Real-time RT-PCR reaction was performed using an Applied Biosystems 7500 Fast Real-Time PCR thermo cycler.

A primer probe combination from a conserved region of the $\mathrm{M}$ gene APMV I F M+4100 5'-AGT GAT GTG CTC GGA CCT TC-3', APMV I R M- 4220 5'-CCT GAG GAG AGG CAT TTG CTA-3' and Probe APMV-1 M+4169 5'-FAM TTC TCT AGC AGT GGG ACA GCC TGC BHQ -3' [14] was used to amplify all NDV isolates. The M-gene positive samples were run by a second primer-probe set Forward $\mathrm{F}$ +4829 5'-GGT GAG TCT ATC CGG ARG ATA CAA G-3', Reverse Primer F- 4939 5'-AGC TGT TGC AAC CCC AAG-3' and Probe F +4894 5'-FAM -AAG CGT TTC TGT CTC CTT CCT CCA-BHQ -3' [13] to specifically detect only pathogenic strains of NDV.

For M-gene assay, the following amounts of reagents per $25 \mu \mathrm{l}$ reaction were used: $5 \mu \mathrm{l}$ of kit-supplied PCR buffer $(5 \mathrm{x}), 0.5 \mu \mathrm{l}$ of each primer $(20 \mathrm{pmol}), 0.5 \mu \mathrm{l}$ of probe $(6 \mathrm{pmol}), 0.8 \mu \mathrm{l}$ of kit-supplied deoxynucleoside triphosphates (final concentration: $320 \mu \mathrm{M}$ each), $1.25 \mu \mathrm{l}$ of $25 \mathrm{mM} \mathrm{MgCl} 2$ (combined with $\mathrm{MgCl} 2$ in kit-supplied buffer, final concentration $3.75 \mathrm{mM}$ ) and $0.5 \mu \mathrm{l}$ of $13.3 \mathrm{u} / \mu \mathrm{l}$ of RNase inhibitor (Promega, Madison, Wis) and $1 \mu \mathrm{l}$ Qiagen enzyme mix and 6.95 Rnase free water. The mix for $\mathrm{F}$ gene assay is similar except the volume of probe which was increased to $1 \mu \mathrm{l}$ per reaction. For each primer set, the reverse transcription (RT) step was $30 \mathrm{~min}$ at $50^{\circ} \mathrm{C}$, followed by 15 min at $95^{\circ} \mathrm{C}$. The cycling conditions for the APMV-1 matrix primers consisted of 40 cycles of $10 \mathrm{~s}$ of denaturation at $94^{\circ} \mathrm{C}, 30 \mathrm{~s}$ of annealing at $52^{\circ} \mathrm{C}$, and extension at $72^{\circ} \mathrm{C}$ for $10 \mathrm{~s}$. For the $\mathrm{F}$ gene primer set, the cycling condition is similar except the annealing temperature that was determined to be $58^{\circ} \mathrm{C}$. The reporter dye (FAM) signals were measured at the extension step of each cycle, and the threshold cycle $(\mathrm{Ct})$ for each sample was calculated. The samples that had a $\mathrm{Ct}$ value $<35$ were considered positive in both $\mathrm{M}$ and $\mathrm{F}$ genes based real-time PCRs.

\section{Data Management and Analysis}

The data was summarized and compiled by summing up the laboratory findings of the study subjects. The coded data was stored in Microsoft Excel 2007 spread sheet and transferred to SPSS Version 16 for statistical analysis. Accordingly, descriptive statistics such as percentage and frequency were used to describe the result.

\section{Results}

Out of the 155 sera samples tested, 18 were positive for NDV antibodies. The overall sero-prevalence in the study areas was $11.61 \%$ at $95 \%$ CI. There was no significant differences among the three districts $(\mathrm{P}>0.05)$ though a wide variation of sero-positivity was observed in between Bishoftu (6\%) and Tikur wuha (16.4\%) districts (Table1). 
Citation: Terefe D, Belaineh R, Chaka H, Sombo M, Mekuria A, et al. (2015) Serological and Molecular Study of Newcastle Disease Virus in Village Chickens in Selected Rift-Valley Areas, Ethiopia. J Veterinar Sci Technol 6: 264. doi:10.4172/2157-7579.1000264

Page 3 of 4

\begin{tabular}{|c|c|c|c|}
\hline $\begin{array}{l}\text { Sampling } \\
\text { district }\end{array}$ & $\begin{array}{l}\text { Number } \\
\text { samples(n) }\end{array}$ & $\begin{array}{l}\text { C-ELISA } \\
\text { positive(n) }\end{array}$ & $\begin{array}{l}\text { Prevalence (in } \\
\% \text { ) }\end{array}$ \\
\hline Bishoftu & 50 & 3 & 6 \\
\hline Tikur-wuha & 55 & 9 & 16.4 \\
\hline Ziway & 50 & 6 & 12 \\
\hline Total & 155 & 18 & 11.6 \\
\hline
\end{tabular}

Out of 155 tracheal swabs samples tested, 13 samples were HA/HI and M-gene RT-PCR positive among which $38.5 \%$ were virulent strains (F-gene RT-PCR). The overall prevalence of APMV1 was $8.4 \%$. Among the three districts, the highest prevalence was observed in Bishoftu (12\%) followed by Tikur wuha (11\%) and the least were recorded in Ziway (2\%). No significant difference was observed $(\mathrm{P}>0.05)$ in between the districts (Tables 2 and 3 ).

Table1: Overall and district based sero-prevalence of Newcastle disease virus in selected districts of Rift Valley areas.

\begin{tabular}{|l|l|l|l|l|}
\hline District & Number of samples(n) & HA/HI \& M gene RT-PCR positive (n) & Prevalence (in \%) & $\begin{array}{l}\text { F-gene RT-PCR positive } \\
\text { (n) }\end{array}$ \\
\hline Bishoftu & 50 & 3 & 6 & 2 \\
\hline Tikurwuha & 55 & 9 & 16.1 & 2 \\
\hline Ziway & 50 & 1 & 2 & 1 \\
\hline Total & 155 & 13 & 8.4 & 5 \\
\hline
\end{tabular}

Table 2: Percentage of NDV detected by HA/HI and real-time RT-PCR based methods in selected districts in rift valley areas.

\begin{tabular}{|c|c|c|c|c|}
\hline Sample ID & District & HA titer $(\log 2 x)$ & Ct- value for M-gene RT PCR & CT- value for F-gene RT- PCR \\
\hline B1 & Bishoftu & 7 & 18 & 26 \\
\hline B2 & Bishoftu & 6 & 19 & 27 \\
\hline B3 & Bishoftu & 7 & 22 & - \\
\hline T1 & Tikurwuha & 8 & 24 & 31 \\
\hline T2 & Tikurwuha & 8 & 27 & - \\
\hline T3 & Tikurwuha & 7 & 28 & - \\
\hline T4 & Tikurwuha & 8 & 28 & - \\
\hline T5 & Tikurwuha & 6 & 28 & - \\
\hline T6 & Tikurwuha & 6 & 22 & 30 \\
\hline T7 & Tikurwuha & 8 & 19 & - \\
\hline T8 & Tikurwuha & 7 & 31 & - \\
\hline T9 & Tikurwuha & 6 & 29 & - \\
\hline $\mathrm{Z1}$ & Ziway & 8 & 18 & 25 \\
\hline Mean Values & - & 7.1 & 24.1 & 27.8 \\
\hline
\end{tabular}

Table 3: HA titer and Ct values of the NDV isolates obtained from selected districts in rift valley areas.

\section{Discussion}

In the present study, the overall sero-prevalence of ND in the study districts was $11.6 \%$. This is in agreement with earlier studies in southern Ethiopia in which a prevalence of $11 \%$ was reported [15]. However, the finding was considerably lower than the previous reports by Zeleke et al [10] and Tadesse et al [11], in which sero-prevalence of $19.8 \%$ and $32.2 \%$ were reported in rift Valley areas and central Ethiopia respectively. On the other hand, the result of the present study was higher than the findings of other studies in Eastern shewa and Kersakondaltity district where sero-prevalence of $5.9 \%$ and $5.6 \%$ were recorded respectively $[4,16]$. These variations could have been attributed to seasonal differences during sampling periods and methods employed for the studies. In the current study, lower seroprevalence (6\%) was recorded in Bishoftu, compared to other districts. According to Awan et al [17] low prevalence is suggestive of an interepidemic phase and this could partly explain the high proportion of sero-negative chickens in the district. Relatively, higher prevalence was 
recorded in Tikurwuha (16.4\%) and Ziway (12\%) districts though the difference was not statistically significant in between the districts. Suggesting the wide spread presence of the disease in the study areas.

Our study also indicated the circulation of NDV in village chickens in the study areas. In total, $8.4 \%$ of the swab samples were positive for NDV of which $38.5 \%$ were virulent strains. The finding is in agreement with earlier studies which revealed the circulation of virulent strains of NDV in village chickens in Ethiopia [18,19]. The first documented evidence of ND in Ethiopia dates back to 1978 when an outbreak occurred in Eritrea, the then, Northern part of the country. Since then, the disease has become endemic in village poultry population and thus it recurs every year inflicting heavy losses [20].

In all NDV positive chickens, Anti-NDV antibodies were detected showing strong correlation between the NDV infection and seroprevalence. Suggesting that, ND in village chickens in these districts may result in a constant cycle of infection that periodically boosts the immunity of all exposed chickens [21]. Free range management system in village chickens that allows the uninterrupted cycle of infection as the virus passes from one age to another may also be a cause of this endemicity.

However, high proportions of sero positive chickens (83.3\%) were negative for NDV in Ziway district. Indicating that the birds have previously been infected by the non virulent strains or survived outbreaks of the virulent NDV strains [22]. The presence or absence of detectable antibody levels within a flock depends also on the phase of infection at the time of sampling [23].

In conclusion, this study revealed that, both avirulent and virulent strains of NDV are co circulating in village chickens in rift valley areas in Ethiopia.Implying that ND is continuous to be a threat to village chicken production system. In addition, there could be a spillage over effect in which village chickens can serve as source of infection for the growing small scale poultry farms in the country or vise-versa. Thus, due attention should be given to control the disease in village chicken settings through implementation of appropriate vaccination strategies. Our study highlights the importance of continuous sero-surveillances complemented with virus isolation and genetic characterization of the circulating strains to better understand the epidemiology of Newcastle disease virusto allow appropriate control decision to be taken.

\section{Acknowledgements}

This study was supported by National Animal Health Diagnostic and Investigation Center (NAHDIC), Ethiopia. The authors would like to thank the Molecular Biology and Serology Laboratory staffs of NAHDIC for their technical assistance and support in processing the samples.

\section{References}

1. Permin A, Hansen J (1998) Epidemiology, diagnosis and control of poultry parasites. In: FAO Animal Health Manuals (4Edn) FAO, Rome.

2. Regmi A (2001) Changing structure of global food consumption and trade. Economic Research Service, US Department of Agriculture and Trade, Washington DC.

3. Eshetu Y, Mulualem E, Ibrahim H, Berhanu A, Aberra K (2001) Study of gastro-intestinal helminths of scavenging chickens in four rural districts of Amhara region, Ethiopia. Rev Sci Tech 20: 791-796.
4. Chaka H, Goutard F, Bisschop SP, Thompson PN (2012) Seroprevalence of Newcastle disease and other infectious diseases in backyard chickens at markets in Eastern Shewa zone, Ethiopia. Poult Sci 91: 862-869.

5. Mayo MA (2002) A summary of taxonomic changes recently approved by ICTV. Arch Virol 147: 1655-1663.

6. Steward M, Vipond IB, Millar NS, Emmerson PT (1993) RNA editing in Newcastle disease virus. J Gen Virol 74: 2539-2547.

7. Abolnik C, Horner RF, Bisschop SP, Parker ME, Romito M, et al. (2004) A phylogenetic study of South African Newcastle disease virus strains isolated between 1990 and 2002 suggests epidemiological origins in the Far East. Archive of Virology 149: 603-619.

8. Otim MO, Christensen H, Jørgensen PH, Handberg KJ, Bisgaard M (2004) Molecular characterization and phylogenetic study of newcastle disease virus isolates from recent outbreaks in eastern Uganda. J Clin Microbiol 42: 2802-2805.

9. Miguel E, Grosbois V, Berthouly-Salazar C, Caron A, Cappelle J, et al. (2013) A meta-analysis of observational epidemiological studies of Newcastle disease in African agro-systems, 1980-2009. Epidemiol Infect 141: 1117-1133.

10. Zeleke A, Sori T, Gelaye E, Ayelet G (2005) Newcastle disease in village chickens in the southern and rift valley districts in Ethiopia. Int J Poult Sci. 7: 507-510.

11. Tadesse S, Ashenafi A, Aschalew Z (2005) Sero-prevalence study of Newcastle Disease in local chickens in central Ethiopia. Int J Appl Res Vet Med 3: 25-29.

12. Alexander DJ and Senne DA (2008) Newcastle disease and Other Avian Paramyxoviruses. In: A Laboratory Manual for the Isolation, Identification and Characterization of Avian Pathogens (4thedn) Athens, American Association of Avian Pathologists, pp: 135-141.

13. OIE (2013) Newcastle disease. Manual of Diagnostic Tests and Vaccines for Terrestrial Animals: Mammals, Birds and Bees.

14. Wise MG, Suarez DL, Seal BS, Pedersen JC, Senne DA, et al. (2004) Development of a real-time reverse-transcription PCR for detection of newcastle disease virus RNA in clinical samples. J Clin Microbiol 42: 329-338.

15. Getachew B, Moses N, Kyule, Melese B, Fufa D (2014) Sero-prevalence of Newcastle Disease Virus Antibodies in Village Chickens in Kersanakondalaity District, Ethiopia. Global Veterinarian 12: 426-430.

16. Regasa C, Fufa D, Berihanu S, Hunduma D (2007) Sero-prevalence of Newcastle disease in backyard chickens in mid rift valley of Oromia, Ethiopia, Work Poster, Assoc Inst Montpellier, France. Tropic Vet Med p. 121.

17. Awan MA, Otte MJ, James AD (1994) The epidemiology of Newcastle disease in rural poultry: a review. Avian Pathol 23: 405-423.

18. Chaka H, Goutard F, Gil P, Abolnik C, Servan de Almeida R, et al. (2013) Serological and molecular investigation of Newcastle disease in household chicken flocks and associated markets in Eastern Shewa zone, Ethiopia. Trop Anim Health Prod 45: 705-714.

19. Mulisa DD, W/Kiros MK1, Alemu RB1, Keno MS1, Furaso A2, et al. (2014) Characterization of Newcastle Disease Virus and poultry-handling practices in live poultry markets, Ethiopia. Springerplus 3: 459.

20. Tadelle D, Jobre Y (2004) A review of the importance and control of Newcastle disease in Ethiopia. EthiopVet J 1: 71-81.

21. Sagild IK, Haresnape JM (1987) The status of Newcastle disease and the use of V4 vaccine in Malawi. Avian Pathol 16: 165-176.

22. Abdullsattar F (2004) Newcastle disease. Vet Medicine Journal 1: 157-165.

23. Bell JG, Mouloudi S (1988) A reservoir of virulent Newcastle disease virus in village chicken flocks, Preventive Veterinary Medicine 6: 37-42. 